\title{
THE NATURE OF LEGAL CERTAINTY ON THE UTILIZATION OF THE RESULTS OF DEOXYRIBONUCLEIC ACID (DNA) IN THE PROCESS OF SCIENTIFIC INVESTIGATION
}

\author{
${ }^{1}$ Mauluddin M, ${ }^{2}$ H. Hambali Thalib, ${ }^{3}$ H. Sufirman Rahman, ${ }^{4}$ Syamsuddin Pasamai \\ ${ }^{1} \mathrm{Ph} . \mathrm{D}$ Candidate, Postgraduate Student of University of Muslim Indonesia \\ ${ }^{2,3,4} \mathrm{Faculty}$ of Law, University of Muslim Indonesia
}

\begin{abstract}
The purpose of this study to explain about: (1) the nature of the legal certainty of the results of the DNA examination; (2) the effectiveness of the results utilization of the DNA in the process of scientific investigation in 2007-2016; and (3) support the legislation, human resources, facilities and infrastructure, budgets and the level of knowledge and legal awareness of the public and law enforcement officers in the process of DNA testing. The Methods is a qualitative approach. The location of this scientific research conducted at the DNA Laboratory Medical and Health Center (Pusdokkes). The results showed that: (1) the nature of the rule of law on the results utilization of DNA testing is a means to search for and find the material truth which is absolute and conclusive by promoting evidence categorized as a gold and green qualified (2) the implementation of the DNA utilization testing in the investigation process scientifically in the DNA laboratory have gone quite effective, with the number of cases handled 754 cases and (3) support the legislation, human resources, facilities and infrastructure, budgets and the level of knowledge and awareness of the law in the process of DNA testing will be sufficient.
\end{abstract}

Keywords: deoxyribonucleic acid, scientific investigation

\section{INTRODUCTION}

The era of reform up to this time, awareness of legal consciousness of draft human rights is increasing in line with the increasing quality of public knowledge that was triggered by the increasing threat of terrorism, economic pressures and disasters as well as higher crime rates including conventional and transnational crime. The interests of scientifically proving a crime is now in Indonesia are increasingly required in accordance with the times and the level of quality of evil that exists. Indonesian National Police as carrier executing police duties in the field of law enforcement is required to work in a professional manner. It is given that rising crime in 
International Journal of Arts and Humanities

ISSN: 2581-3102

Volume:02, Issue:03 "March 2018"

Indonesia from year to year, which is followed by the development of technology types of crime are increasingly diverse, so that in any event the offenses are discovered biological evidence at crime scenes in very small quantities. Therefore, it needs the right standards of operation procedures in the sampling of biological evidence in order to obtain a perfect result (Ishaq, 2007; Andayono, 2011).

Deoxyribonucleic acid (DNA) is the smallest unit of living things that are carriers of offspring traits. DNA found in blood, skin cells, muscle, brain cells, bone, teeth, hair, saliva, heart, mucous, urine, and in all human cells. As is known, DNA is the basic material that builds entire genetic characteristics of a person. DNA is present in every human cell and all cells have the same DNA with one another. For example, the DNA contained in skin cells together with DNA found in hair cells and others (Chaniago, 2012). In addition, the DNA is unique to each person's DNA is different from the DNA of another person. Because this is the nature of the DNA can be used as a marker of individual identity, lineage and ethnicity. DNA analysis is widely used to characterize the genetic trait at a molecular level which directly reflects the nature of the genotype (genetic material) that is owned by a particular organism (Ishaq, 2007). DNA tests or checks can be made only with evidence of small amounts of DNA. This is because the used technique called Polymerase Chain Reaction (PCR) or polymerase chain reaction (Rustamaji, 2008). Forensic science is the application of scientific principles and techniques to provide a legal proof in an investigation. Forensic science can also be regarded as the application of science to the law. One example is the application of forensic science of DNA analysis is done by comparing the DNA profile obtained from the suspect or the suspect's DNA profile obtained from the DNA database (Atmadja, 2009).

The existence of evidence or better known as the verification is a very urgent aspects of the court proceedings so that there is certainty and enforcement, because the accuracy of efforts to prove that justice to be realized and it is dependent on the rule of law. Proof accurate is the road to the establishment of justice. But on the contrary, proof of which is inaccurate will bear injustice and legal uncertainty. Even with the evidence the judge will get a clear picture of the events that are being disputed in court. In fact, on the handling of criminal acts are still often encountered no errors and the impression that the investigators slow or wrong in handling particular not maximize DNA testing, which occurs primarily in the mysterious or unknown suspect (Astuti, 2014).

Use and expectations of the DNA test still encountered some obstacles and challenges will be the need for a DNA test. In many criminal cases, such as rape cases mentioned linkages four factors, namely the crime scene, the body or clothing of the victim, the body or clothing perpetrators and the tools used in the crime, such as the penis, which is often described in the prism rectangular 
International Journal of Arts and Humanities

ISSN: 2581-3102

Volume:02, Issue:03 "March 2018"

evidence and is one things that can cause the judge's conviction (Rahardjo et al. 1986). Linkages four factors are not obvious or cannot be found, so the result is not raised confidence in judges who manifests in the form of a lighter sentence or modest. Here are some things that allow this to happen, (Damang, 2011). due to:

1. Problems integrity of the evidence, where the rape victim after the incident embarrassing generally feel disgusted and immediately shower or wash themselves clean, bedspreads containing semen or blood spots often been washed or replaced, the floor was swept and mopped so neatly. When the victim under a doctor's all clean. This sort of thing without realizing it would cause the loss of many objects of evidence such as liquid / spotting semen, hair offender, blood actors and so on needed for evidence during the trial.

2. Technical problems gathering evidence object, in this case the processing of the scene, in which the search did not object evidence for lack of knowledge, lack of experience or carelessness resulting in the loss of important data for the disclosure of the case.

3. Technical problems forensic examination and laboratory, examination ability rape care center varies from one place to another place. No checks sperm at all, it cannot distinguish between blood membrane rips or tears as a result of blunt masturbation. Examination of DNA fingerprinting carried out on material from vaginal swabs not only can reveal the exact date rape, but to detect the number of offenders in cases of rape by many actors. Blood type and DNA fingerprinting on the nail scrapings materials (if casualties scratch) can also be used to find the perpetrator.

4. Technical problems examining physician knowledge, scarcity of forensic doctors namely, where cases of rape and immoral offenses handled by the obstetrician even general practitioners. Ignorance about the principle of gathering evidence and how to examine objects made much important evidence overlooked and not be detected during the inspection.

5. Problems knowledge of law enforcement officers, often a mistake in making the allegation that the suspect be made free at all, because the investigator, prosecutor and judge considers just need to look for evidence in the form of recognition defendant and ignore scientific evidence through medical examination and expert testimony.

Another problem that Indonesia has not maximized the DNA test, but DNA Profiling or determination of DNA fingerprinting has been used by several countries as a means of solving the case or criminal law. Examples of cases that have been successfully solved using DNA fingerprinting are a murder case. By determining the DNA of ownership, the actors genetic evidence left at a crime scene can be captured (Pusdokkes POLRI, 2015). The technological advances of DNA and DNA polymorphism discovery have enabled the manufacture of individual DNA databases for criminal investigation purposes. Many ethical and legal issues arising in the preparation of the DNA database and this issue is very important when one 
International Journal of Arts and Humanities

ISSN: 2581-3102

Volume:02, Issue:03 "March 2018"

analyzes the legal regulations on this matter (Fardhinand, 2015). The description has been described above, showed that there had been a gap between the expectations (law in books) with reality (law in action) in the handling of criminal acts, particularly if associated with the use of DNA testing. The study of the nature of legal certainty on the utilization of DNA (deoxyribonucleic acid) testing in the process of scientific investigation to be important and interesting to study.

\section{LITERATURE REVIEW}

\section{The Theory of Nature}

The term comes from the word "Al-Haqq", which means truth. Told Science Itself it means science that is used to search for the truth. Then some experts to formulate its definition as follows:

a. Ash-Shaykh Abu Bakr Al-Ma'Ruf said: "The essence is (psychological atmosphere) a Saalik (Shufi) when he reaches a goal, so that he can see (signs) of divinity in the eyes his heart ".

b. Imam Al-Qasyairiy said: "The essence is witnessing something that is predetermined, predestined, hidden (undisclosed) and which has been declared (by Allah to His servant."

The essence obtained by Shufi after a long take the Order to always pursue Suluk, making him sure of what he faced. Therefore, cleric Shufi often has three degrees of confidence:

a. Ainul Yaqqin; namely tiers confidence caused by the observation sense of the universe, giving rise to the belief of the truth of God as creator;

b. Ilmul Yaqqin; ie degree conviction caused by analysis of thought when he saw the greatness of God in this universe;

c. Haqqul Yaqqin; that is a belief which is dominated by conscience Shufi without going through His creation, so that all speech and behavior containing the value of worship to God. And the truth of God directly witnessed by the liver, without being able to doubt by sense decision ".

Another name of the theory is a theory about the nature of the circumstances (Langeveled), while ontology, which is often also called metaphysics, is part of a theoretical nature. What is the essence? The essence is the reality, the reality is all real early, "real" means the actual reality, the actual state of things, not a mere state or a state that is deceptive, not changing circumstances. See this supposition. Basically the democratic government values the opinions of the people. Perhaps it had seen the government's arbitrary conduct, does not respect the opinion of the 


\section{International Journal of Arts and Humanities}

ISSN: 2581-3102

Volume:02, Issue:03 "March 2018"

people. It is a temporary state and not the essence. Whether real or not? No. Mirage it is not essential (Psychology, 2012).

Prior to the formula, the arguments or the laws of the universe truth seekers formulated by the nature of truth, or the scientists, where the truth is hiding? In short, before civilization can talk about scientific truth because the truth types had not been found at the time was the truth given the "brand" anything and belongs to whom? With the language of religion, perhaps we could call, when the truth is still hidden in the hand of God. At that time no one has asked about the truth in earnest, through diligent work, put on trial, reflection, and systematic observation of the various symptoms of the universe. In those days the truth belongs to God alone, and we call it divine truth: the only kind of truth and the source of all kinds of truth.

Truth is something that can be said to be true by reason logically and analytically. A truth can be seen from the viewpoint and a different method of each person, so that each person can express his opinion on the truth. For example, the truth from the standpoint of rationalism and empiricism. Rationalism derived word meaning reasonable ratio / mind, an understanding which teaches that the true source of knowledge that is the ratio of (a mind). While empiricism is understood that teaches that the true source of knowledge that only experience gained through the senses of a person. Conflicting ideologies can bring up the theory of truth (Imadha, 2013). Traditionally, we know of three (3) that the coherence theory of truth, correspondence, and pragmatic. And there are five (5) theory of truth in science, namely: coherence truth, the truth of correspondence, performative, pragmatic truth, and A Propositional truth, even added one more theory that paradigmatic truth.

1. The Coherence of Truth Theory that lack of compatibility or harmony between something else with something that has a higher hierarchy than anything elements, either in the form of schemes, System, or value. Coherence bias on the order of rational and sensual in the context of the transcendental. Coherence theory can also be called the theory of consistency, the theory says, a statement considered to be true if the statement is coherent or consistent with previous statements that have been considered completely logical.

2. The Correspondence of truth theory, correspondence theory holds that a statement is said to be true if the knowledge contained material that statement corresponding (associated) with the statement that exist in nature or an object such statements. Correspondence of thinking is thinking about the evidence of something that is relevant to something else. Relevant correspondence evidenced by the events that are in line or opposite directions between the reality of the fact that the expected.

3. Performative Theory of Truth is the truth that decided or proposed by certain authorities. Society can think of a thing is true, though sometimes at odds with empirical evidence. In 
International Journal of Arts and Humanities

ISSN: 2581-3102

Volume:02, Issue:03 "March 2018"

everyday life, people sometimes have to follow the truth performative. Namely government authorities, religious leaders, traditional leaders, community leaders, and so on. Performative truth tends to make people less initiative and innovative, because they are just following the truth of authority, so it is not used to think critically and rationally.

4. Pragmatic theory of truth, pragmatic theory says that the statement is measured by the criterion of whether the statement is functional in practical life. That is, a statement is true if the statement or the consequences of that statement has practical utility in human life.

5. A Propositional theory of truth, according to Aristotle, a proposition (statement) is said to be true when in accordance with the formal requirements of a proposition. Then another opinion of Euclides, the proposition is true is not visible from the formal true, but seen from the right according to its material.

6. Paradigmatic theory of truth that is a theories that right when the theory was based on the paradigm or a particular perspective and a community of scientists who recognize the paradigm. Paradigmatic truth is actually the development of the truth of correspondence.

\section{Theory of legal certainty}

Certainty is a matter of (state) certainly, conditions or provisions. Intrinsically law must be certain and fair. Definitely as behavior and fair guidelines for behavior guidelines that should support an order which is considered reasonable. Just because it is fair and conducted by law certainly be able to function. According to him, certainty and fairness is not just a moral imperative, but in fact characterize the law. A law is uncertain and would not fair is not just bad law, but not a law at all. Both properties were included understand the law itself (den begriff des Rechts). Law is a collection of rules or principles in a life together, the overall rules of conduct that apply to a life together, which can be forced to implement the sanction. Legal certainty is a characteristic that cannot be separated from the law, especially for written legal norms. The philosophy in the science of law that, where there is no rule of law, there is no law (Ubi jus incertum, ibi jus nullum). Law no certainty value will lose meaning because it no longer can be used as a code of conduct for all (Hiariej, 2012). According Apeldoorn, the rule of law has two aspects. First, the matter cans be-determined (bepaalbaarheid) law in matters of money concrete. This means that those who seek justice want to know whether that be in terms of specific legal, before he started the case. Secondly, legal certainty means that the legal security. That is, the protection of the parties against the tyranny of judges.

\section{Law Enforcement theory}

Definition of law enforcement can also be interpreted as the implementation of the law by law enforcement officials and everyone who has an interest in accordance with their respective authorities according to the applicable law. Enforcement of criminal law is an integral process 
International Journal of Arts and Humanities

ISSN: 2581-3102

Volume:02, Issue:03 "March 2018"

begins with the investigation, arrest, detention, court accused and ends with correctional convicts. According by Soekanto (2010) is the law enforcement activities of harmonizing relationships that span the 'hierarchy values of the rules of steady and attitude acts as a series of translation of the value of the final stage. To create, maintain and sustain peace social life. Enforcement of criminal law is a concrete application of criminal law by law enforcement officials. In other words, enforcement of criminal law is the implementation of criminal laws. Thus, the rule of law is a system that involves the harmonization between the rules and the value of real human behavior. The rules are then being a guideline or benchmark for behavior or act that is considered appropriate or should be. Behavior or attitude that follow aim to create, maintain, and sustain peace.

\section{Proof theory}

Proof is the central point examination of the case in court. Proof is provision - the provision that contains hatching and guidelines on how to - how justified laws - laws which the accused prove the guilt of the accused. Understanding of the actual proof will not be found in any article that gives a good setting in the Criminal Code or in other legal provisions. Proof is one of the processes that are essential to the effort of finding the material truth of a criminal case, so that in the process of proving the case in court needed evidence and the evidence is right - really can make light of a criminal offense who expect him.

\section{Theory of Law Effectiveness}

According by Soekanto (2004) that one function of the law, either as a rule or as an attitude or behavior is to guide human behavior. The problem not only limited legal effect on the incidence of adherence or compliance with the law, but includes the total effect of the law against acts of attitudes or behaviors, both positive and negative. The effectiveness of law enforcement is very closely linked to the effectiveness of the law. So that laws are effective, it would require law enforcement agencies to enforce the sanctions. A sanction can be actualized to the public in the form of adherence (compliance), with these conditions indicates an indicator that the law is effective. According by Mudzhar (2015) that basically the law was created to regulate the human order achieve order. Law or rule with justice is a collective need, because the rule of law is something that is the sine qua non for the preservation of an orderly life. However, in practice sometimes we find how the law was not running optimally, which in turn that desire cannot be realized. Mudzhar (2015) is one of the Indonesian Muslim scholar gives some figures so that the law or a rule can run effectively. A rule will not be effective if only in the form of an appeal and a mere suggestion, especially if the low awareness of the law in a society.

\section{Description of DNA Utilization}


International Journal of Arts and Humanities

ISSN: 2581-3102

Volume:02, Issue:03 "March 2018"

The judicial proceedings, generally permitted (halal) goods collected by police investigators are shown. However, the perpetrators often do not recognize on the evidence and what has been alleged, so the judge in doubt over the authenticity of the evidence. Here, the role of sciencebased technologies that scientific knowledge plays to clarify and connect evidence and other findings that have been collected by police investigators in the field. DNA is a genetic material that exists within human cells. Every part of the body of an individual human beings have the same DNA, such as DNA from blood would be similar / identical to the DNA from the hair, bones, saliva / saliva and so forth. Profit DNA of each human being is unique and there is none among humans. The existence of DNA in the cell nucleus caused his condition is stable so it will not change, of the human being in the womb until the man buried in the ground. Although DNA is unique and individual, DNA profit comparison can be drawn from the DNA of other people who have a biological relationship, such as parents or children, for inherited half of its DNA from the father and half from the mother, thus simplifying the process of matching (Widodo, 2016).

DNA testing has been able to do by the police since the 90s, which in this period are still using conventional methods and would require the workmanship is quite time consuming. Currently, DNA Laboratory Pusdokkes Police has been applying the methods and DNA technology which has been used International, so that the results of DNA testing is scientifically and recognized. The results of DNA testing in the form of profit-profit-DNA will be stored into the data bank of DNA that will be used to connect between the evidence, crime scene, witnesses, victims and suspects in order to get the clear picture of the modus operandi of criminal acts occur (Larasati, 2013).

DNA in cells of the human body is in the cell nucleus and mitochondria. Examination of DNA by DNA laboratory Pusdokkes Police focused on the DNA in the cell nucleus that long linear shape and is arranged in a compact structure of chromosomes stable. One role of DNA in the disclosure of a criminal case proved in 2008, in which pieces of human flesh was found on a bus Mayasari Bhakti P64 Pulogadung - Kalideres. This case includes a difficult case because the witness (a bus conductor who found a package containing pieces of human flesh) does not know clearly alleged passengers leaving the package. Continued intensive inspection of the pieces of human flesh indicates that there is former oil attached to the evidence. If the place of the crime scene (TKP) obtained a DNA profile match between the bloods spots on the wall and the door frame with pieces of human flesh, so that it can be concluded that the victims were killed in the house. The results of DNA testing against evidence collected from a crime scene in the form of a letter can be used as legal evidence in court proceedings, in accordance with Article 184 paragraph 1 of the Criminal Code. Further, statement or opinion of the examiner DNA Nadir in court which is called by statements of experts can make light of a case, as he had done a criminal 
International Journal of Arts and Humanities

ISSN: 2581-3102

Volume:02, Issue:03 "March 2018"

case related to the example above. Thus it can be said that the exclusion of the examination process of the DNA of any evidence gathered from crime scenes by the investigator makes the process of disclosure of a case tends to be faster and focused.

\section{METHODS}

The scientific research conducted at the Laboratory of DNA Police Medical and Health Center is located at Jl. New Cipinang Raya No. 3B East Jakarta and Southeast Sulawesi Regional police office. The approach in this study used a qualitative approach. The study population consisted of civil servants and members of the Police and citizens. Samples were determined purposively namely Personnel Laboratory of DNA Pusdokkes Police as many as 10 people, personnel physician Police (dokpol) in the ranks of Medical Science and Health (Biddokkes) regional police (Polda) in Southeast Sulawesi as many as 30 people, investigators in the police force of Southeast Sulawesi as many as 40 people, and citizens who have anything to do with the implementation of DNA testing in the laboratory of the National Police Pusdokkes DNA of 20 people. Types and sources of data consist of primary data, secondary data and literature data. Data collected in this study with several ways: interviews, questionnaires, observation and documentation. Analysis frequency and percentage with SPSS 18 is using in this study.

\section{DISCUSSION}

Overview DNA Laboratory Medicine Center for Health (Pusdokkes) Police DNA Laboratory pioneered by Dr. Christanto TH (Alm), Dr. Slamet Poernomo, drg. Alphonsus G, dr. Lukman Hakim, Drs. Putut T. Widodo and Sri Aminarni (Alm), during the period 1990-2005 with activities such as serology test, Dot Blot (1992), Organic Isolation Validation (1993), HLA DQA (Early of 1994), D1S80 (late of 1994) and SA Gel Electrophoresis.So that at the beginning of the laboratory pioneered a series of validations conducted, DNA isolation technique called "Alpusri" managed and used as a mainstay method. The name "Alpusri" derives from the combination of three personnel medical doctors, namely, Alphonsus RQ, Putu T. Widodo, and Sri Aminarni.

Rehabilitation and construction of a new DNA laboratory by the police in collaboration with the Australian Federal Police (AFP) conducted in 2006 to 2007, until March 26, 2007 Police Pusdokkes DNA Laboratory, which was inaugurated by the Chief of Police and the Australian Federal Police Commissioner. DNA laboratory Police Pusdokkes a forensic DNA laboratory, where forensic DNA laboratories have the highest inspection standards and can be used in criminal cases, but can also be used for the benefit of the process of identifying such cases Disaster Victim Identification (DVI). Since 2007 Laboratory of DNA have been able to handle the types of cases of murder, mutilation, rape, paternity, missing persons, DVI and terrorism with 
International Journal of Arts and Humanities

ISSN: 2581-3102

Volume:02, Issue:03 "March 2018"

more than 160 cases with a sample of more than 1000 pieces. Among the cases that can be handled are included murder case by Veri Idham in Jombang, citizen victims of forest fires in Victoria State of Australia, Sukhoi plane crash cases and cases of terrorism. Construction of a DNA database of criminal offenders in Indonesia is also done by the DNA Laboratory of the Police Pusdokkes gradual and sustained in 2009.

\section{The essence of the Legal Certainty DNA testing results}

Legal have ruled characteristics and forbid, have the nature of force, have the binding power of physical and psychological. Because the law has the characteristics, properties and binding power, then the law can give justice, is to be able to determine who is wrong and who is right, has the right to punish wrong, the law can force compliance with regulations, and impose penalties for violating sanctions. As evidence in court, the DNA test of evidence has been frequently used universally in the world. This is understandable due to such cases it is highly likely perpetrator left the ingredients are DNA samples, such as blood, hair, skin cells, saliva, semen (sperm), sweat, and others. In addition, many also became evident that the results of DNA tests may send the guilty to jail or prevent inserted innocent people in prison.

DNA testing can identify errors someone with a higher degree of certainty, because the basis of the DNA sequence of each individual is unique. In the application of this forensic, DNA technology is used RFLP analysis. The outcome rather than the analysis that the pieces of fragmentation separated by electrophoresis. This method was used to compare DNA samples of suspects (e.g. the murder of criminal suspects), the victim, and a small amount of semen, blood or other tissue found at the crime scene. Based on the above, it can be explained that the application of DNA technology in the field of forensic medicine, the use of DNA analysis for forensic settlement cases have also increased. The role of DNA testing in the law enforcement process can be seen from the use of technology for the DNA test:

1. Personal identification, performed in cases of unidentified victims of the invention, as in the case of an accident, murder, mass disasters, aircraft accidents.

2. Tracking the genetic relationships (disputed parentage or cases of doubt the parents). Tracking the relationship between children and parents is done in cases of suspected infidelity, the case of doubt the father, mother hesitated case, the case of babies swapped, immigration cases.

3. Tracking the source of biological material is the examination of evidence of microscopic (trace evidence) in order to find the perpetrator of the offense of decency (examination spotting semen, swabs of the vagina, scraping of the nail), searching for victims (blood spots on clothing suspects at the scene, as well as the analysis of cells in the bullet cytology), as well as analysis of body parts in the case of mutilation. 


\section{Utilization Effectiveness Pusdokkes DNA Laboratory}

Police investigation in the investigation process Scientifically Year 2007-2016 The number of cases revealed with the help of DNA testing laboratory DNA Pusdokkes handled by the Police in the past 10 years (2007-2016) shows the development of the case are likely to increase. More details are shown in the picture below:

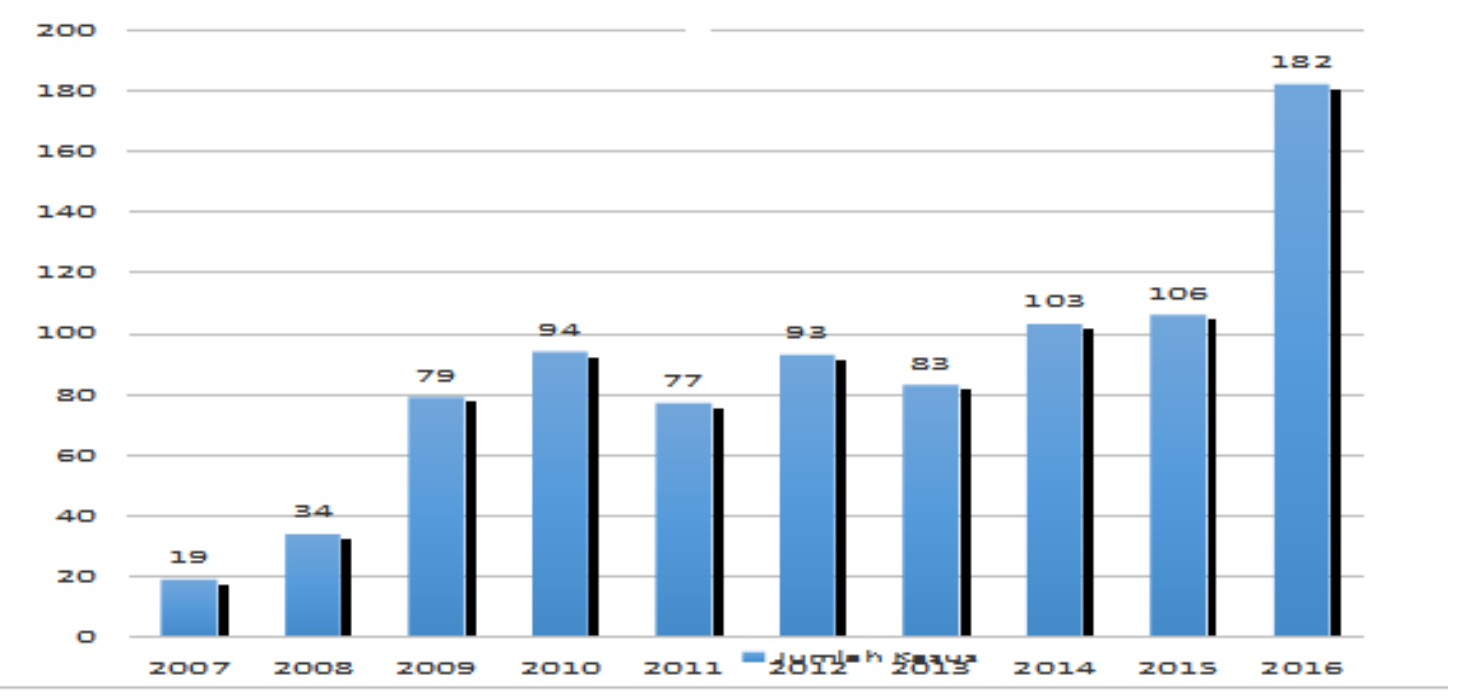

Figure 1. Number of cases handled by the DNA Laboratory 2007-2016

Based on the above diagram shows in the past 10 years the number of cases handled by the DNA Laboratory Pusdokkes Police underwent different changes. There were changes in the number of cases increased from 2007; there were 19 cases in 2010 increased up to 94 cases. In the year 2011 decreased cases: 77 cases and then increased in 2012 as many as 93 cases in 2013 decreased to 83 cases. After that there was an increase from 2014 to 2016 reached 182 cases.

Factors Support of Regulation Legislation, Human Resources, Infrastructure and Budget, And Level of Knowledge and Awareness Law of Society and Law Enforcement In the process of DNA testing

Legislation Implementation of DNA testing in the investigation process scientifically require any regulatory support adequate legislation so that every law enforcement officers can carry out the tasks and authority quickly and accurately, and can be avoid the law enforcement personnel from the potential errors or mistakes in the handling of criminal offenses and other cases. Law enforcement and law enforcement in Indonesia is still far from perfect. Expectations of the 
International Journal of Arts and Humanities

ISSN: 2581-3102

Volume:02, Issue:03 "March 2018"

people to obtain insurance and legal certainty are still very limited. Enforcement and implementation of the law has not been run in accordance with the principles of justice and truth. Data showing as many as 77 people or $77 \%$ said that the support of legislation in the utilization of the results of the DNA examination is very adequate and sufficient. It can be concluded that the majority of respondents expressed support for appropriate legislation in the implementation of DNA testing. But there are still quite a lot of respondents who consider that the support of legislation in the utilization of the results of DNA testing is inadequate as 22orang or 22\%, so it needs to be further explored barriers factor.

\section{Human Resources}

Motion of law reform that is not increased guidance to its agents, will result in laws that are not updated will not mean anything. Goodness and perfection would disappear into slowness, conceit, harshness, and corruption of law enforcement officials, splendor and perfection of criminal procedural law greatly determined by the merits of the implementation apparatus. That is, the renewal of criminal procedural law by fostering an increase in the attitude of law enforcement officers, should be run simultaneously in order to avoid a gap between law reforms with the mental attitude of the administrators. The development of science is always realized through the education process aimed at improving the relationship between general knowledge and human experience to the environment as a whole. The development of knowledge is not born or created spontaneously, but through a process of conscious sustainability and based on the needs of the knowledge that is usually tailored to the job or profession for humans. The analysis showed as many as 68 people or $68 \%$ said that the support of human resources in the utilization of the results of the DNA examination is very adequate and sufficient. It can be concluded that the majority of respondents expressed support for appropriate legislation in the implementation of DNA testing. Looks still quite a lot of respondents who considered that support in the utilization of human resources inadequate DNA test results as many as 31 people or $31 \%$.

\section{Infrastructure and Budget}

Basically the form of facilities or equipment used directly for the continuity of an activity. Normally, tool or these facilities have an important role, because without the support of infrastructure and budget, these activities will not be executed properly. In fact, the activities would not exist without these tools. For example, in education, school or teaching, which is included in the means, are tables, benches, blackboards, classroom, building and others in the school. However, there is one thing that is also included in other forms of means. It is time. Time included in the group means. Time cannot be measured and included in abstract form. But, time is definitely required and interacted directly with the activities carried out. This makes the time fall into this group. Mean while Infrastructure, a public facility that is in the location of the 
International Journal of Arts and Humanities

ISSN: 2581-3102

Volume:02, Issue:03 "March 2018"

activity. When you take the example of education or school activities, the infrastructure can be roads and electricity. Both are needed for the continuity of the main activities at the venue. The analysis showed as many as 87 people or $87 \%$ said that the support infrastructure in the utilization of the results of the DNA examination is very adequate and sufficient. It can be concluded that the majority of respondents expressed support for appropriate legislation in the implementation of DNA testing.

The infrastructure support in the utilization of the results of DNA testing is inadequate as many as 12 people or $12 \%$. Furthermore, to get an idea of the budget support to the Police Pusdokes DNA Laboratory analysis showed as many as 71 people or $71 \%$ said that the budget support in the utilization of the results of the DNA examination is very adequate and sufficient. It can be concluded the majority of respondents stated that adequate budgetary support in the implementation of DNA testing. The respondents considered that the budget support in the use of DNA testing results is inadequate as many as 28 people or $28 \%$.

\section{Level of Knowledge and Legal Awareness}

DNA Laboratory Pusdokkes POLRI in charge of organizing the operation and development of the field of DNA testing at the central and regional support and implement guidance research and development, education and training, a reference center of science and technology DNA lab. To determine the extent of the support and knowledge levels of public awareness about the utilization of the results of DNA testing in the investigation scientific analysis showed as many as 55 people or $55 \%$ said that the support level of knowledge and legal awareness in the utilization of the results of DNA testing is very adequate and sufficient. It can be concluded that the majority of respondents expressed support for the level of knowledge and awareness of community law is adequate in the implementation of DNA testing. Looks still quite a lot of respondents who considered that the budget support in the use of DNA testing results is inadequate as many as $40 \%$.

The level of knowledge and awareness of law enforcement officers of law are essential elements in the context of law enforcement, because the success or failure of law enforcement cannot be separated from the level of knowledge and awareness of legal agents. The level of knowledge and awareness of law enforcement officers will be good or bad references from legal actions of law enforcement officials in the enforcement of criminal acts. To determine the extent of the support level of knowledge and legal awareness of law enforcement officers on the utilization of the results of DNA testing in the investigation scientific analysis showed as many as 76 people or $76 \%$ of respondents said that the support level of knowledge and awareness of law enforcement officers of law is adequate and sufficient, so that it can be concluded that the majority of 
International Journal of Arts and Humanities

ISSN: 2581-3102

Volume:02, Issue:03 "March 2018"

respondents expressed support for the level of knowledge and awareness of law enforcement officers law is adequate.

\section{CONCLUSION}

The essence of the rule of law on the utilization of the results of DNA testing is a means to seek and find the truth material has absolute(absolute) by promoting evidence of significant in criminal matters (real evidence / physical evidence) categorized as "gold" (indicating a direct relationship perpetrators and victim as in evidence blade) and qualified "green" (very good in search of the DNA profile as condoms) that can be held true and there is no doubt at all about the accuracy of the results of DNA test, through the sampling process (goods proof) when the crime scene is done by trained personnel (with the utmost professionalism and code of conduct) to the process of analysis in the laboratory of DNA (in compliance with Good laboratory Practice tested and accredited to ISO17025), so that any criminal investigation and the investigation can unfold into bright and definitely to maximize the benefits of scientific authenticity DNA test has an accuracy of $99.9 \%$, as the use of DNA testing as primary identification method that can stand alone in determining the identity of a person's identity (individual) based on recognized standards Interpol on the disaster victim identification (DVI) operation.

The utilization of the results of DNA testing in the investigation process scientifically in the laboratory of DNA Pusdokkes Police from 2007 to 2016 has been effective, with the number of cases handled by about 754 cases and the number of items of evidence of DNA of approximately 6751 samples, which can be analyzed at $93.63 \%$ and cannot be analyzed because of damage (degradation) of $6.37 \%$. It also fits the support of the Laboratory of DNA in handling some cases in Indonesia, such as the one the completion of the scientific and the presence of legal certainty in cases of improper arrest and identification of victims of "Asrori Tea Garden" behind the series of stories of a serial killer Very Idham Henyansyah in Jombang.

Support legislation, human resources, infrastructure and budget, and the level of knowledge and legal awareness of the public and law enforcement officers in the process of DNA testing is adequate, but there are still some things stand out that needs attention, namely: (a) Lack of device legislation that specifically (lex specialis) regulates the use of the results of DNA testing by police institution, where the existing legal instruments currently only Police Chief Regulation Republic of Indonesia Number 12 Year 2011 on Medical Police are thought to be still specifically regulates the use of DNA technology and to the extent applicable internally. (b) Still insufficient number of specialized DNA laboratory facility handles forensic DNA in Indonesia. (c) Still lack the real number of personnel compared to the needs of the DSP (List of Personnel) in the DNA Laboratory of the Police Pusdokkes as the Indonesian National Police Chief Regulation (the Regulation) No. 6 Year 2017 About the Organizational Structure and Work 
International Journal of Arts and Humanities

ISSN: 2581-3102

Volume:02, Issue:03 "March 2018"

Procedure Environmental police headquarters in the republic of Indonesia (Police Headquarters). (d) Budget support in the implementation of DNA testing in the laboratory of DNA Pusdokkes Police still have fluctuated from year to year, thus affecting the number of samples that can be checked as happened in the year 2011 until 2013. (e) Still low level of knowledge and awareness of the public law regarding DNA testing, DNA-related socialization forensic still devoted to law enforcement officials

\section{REFERENCES}

[1] Abineno, (2014). Had Only Buser Tim Sweet Spot PursueAco.Manado.com News, January 9th, 2014

[2] Achmad Ali. (2009). Reveals Legal Theory (Legal Theory) and Theory of Justice. (Judicial Prudence), Including the Interpretation Act. (Legisprudence), Kencana Prenada Media Group, Jakarta

[3] Achmad, A. and Heryani, Wiwie. (2012). Against Empirical Study Exploring Legal Media Group Publisher Praneda Kencana, Jakarta.

[4] Ahmad, Ali. (2008) Reveals the Reality of Law Anthology Columns and Articles Featured in Legal Affairs, Publisher Kencana, Jakarta.

[5] Andayono, (2011). Role of Forensic Criminal Investigation Police in the Context of Scientific Crime Investigation, paper, Forensic Criminal Investigation Police, Processing Workshop Presented at the scene, at Borobudur, Jakarta, December 21, 2011.

[6] Arniti, Ni Komang Ayu and Budiartha, I Nyoman Putu. (2016) Introduction to Law "Legal Aid for Science Science Reality", Papers Help Legal Studies, University of Warmadewa, Denpasar

[7] Ashraf. (2014). Strength of Evidence Description in Crime Forensics Expert Baby Murder By mother (Case Study in the Syariah Court, Shah Alam, Selangor). Thesis, State Islamic University Sarif Kasim Sultan Riau Pekanbaru.

[8] Astuti, Shellanika Ari. (2014). Strength of Evidence Description In Crime Forensics Expert Baby Murder By mother (Judicial Review Decision No. 147 / Pid.B / 2013 /PN.Pwt.),Thesis, Faculty of Law, University of General Sudirman, Purwokerto.

[9] Atmadja, Djaja Surja. (2009). Forensic examination In Rape Case and Other Complaints offense, Information Reproduction brief introductory lecture Trip information reproduction system for medico Friday, December 25, 2009.

[10] Chaniago, Alfitri Johar. (2012). The existence of DNA as Evidence attrial.Thursday, June 7, 2012, Law Articles.

[11]Damang. (2011). Strength of Evidence: EvidenceLetters,Papers Criminal Law, State Law, November 27, 2011. 
International Journal of Arts and Humanities

ISSN: 2581-3102

Volume:02, Issue:03 "March 2018"

[12]Faal, M. (1991). By filtering Criminal Police (PoliceDeskresi),Publisher PT. Pradnya Paramita, Jakarta.

[13] Fardhinand, Hilman Ali. (2015). The existence of DNA testing (Deoxyribo Nucleic Acid) as a Proof of Evidence in Criminal Law, Articles, Lex crimen Vol. IV / No. 2 / April / 2015.

[14]Fauzi Muhamad. (2017). Evidence regarding DNA testing, Official website.

[15]Forensic. (2010). Laboratory News, Know Closer Criminal Investigation Police Forensic Laboratory,Wednesday, May 12, 2010,

[16] Heriyanto. (2016). Itself Role of Forensic Medicine in Investigation Stage in Process Verification CrimeMurder,Dissertation, Graduate School at University of Muslim Indonesian in Makassar.

[17] Hiariej, Edward Omar Sharif. (2012). Theory and Evidence Law, the publisher, Jakarta,

[18] Imadha, Hariyanto. (2013). Logic: Different Relative Truth and Absolute Truth, Cogito ergo Sum, EksMa Faculty of Philosophy UGM, February 10, 2013,

[19] Ishaq, Musaddeq. (2007). Police Prepare Master Data DNA Crime, Antara News.com, Monday, February 5, 2007.

[20] Larasati, Dinar. (2013). Examination Procedure DNA in DNA Laboratprium Pusdokkes Police, Student Intern Activity Report, Department of Biology, Faculty of Mathematics and Natural Sciences, University of Surakarta.

[21] Mudzhar, Atho. (2015). Construction fatwa in Islam, the Religious Courts, Issue 7

[22] Perdanakusuma, Moses. (1984). The chapters of Forensic Medicine, Publisher Ghalia Indonesia, Jakarta, 1984.

[23] Poerwanto, Hendra. (2010). Definition, Benefits And Objectives Corporate Budget, Budgeting.

[24] Police Research and Development Headquarters POLRI. (2015). And Survey Research Report on the production of DNA Response Prototype vehicle in order to Excellent Service,Jakarta, 2015.

[25] Police, Pusdokkes DNA Laboratory. POLRI (2014). Research Implementation Report (Determination of Minimum Amount muscle and blood samples for DNA testing in the laboratory of DNA Pusdokkes INP) In2014,Jakarta, 2014.

[26] Police, Pusdokkes.POLRI (2012). Technical Guidelines on Sampling DNA for Officers or the Crime Scene Investigators, Jakarta,

[27]Police, Pusdokkes. POLRI (2015). DNA Sampling Technical Guidelines for Crime Scene Officer /Investigator,Second Edition, Jakarta,

[28] Psychology. (2012). Learning Theory Itself, 52,

[29] Rahardjo, Satjipto and Soemitro, Ronny Hanitjio. (1986). Introduction toLaw,Book Topic Module 1-5, the Open University, The Gift, Jakarta 
International Journal of Arts and Humanities

ISSN: 2581-3102

Volume:02, Issue:03 "March 2018"

[30]Rustamaji, Muhammad. (2008). DNA Tests Prove Strength in Glasses Criminal ProcedureCode,Published February 11.

[31] Soekanto, Soerjono. (1983). Factors Affecting LawEnforcement,Publisher UI Press, Jakarta

[32] Soekanto, Soerjono.(2004). Factors Affecting LawEnforcement,Publisher King Grafindo Persada, Jakarta

[33] Soekanto, Soerjono.. (2010). Factors Affecting Law Enforcement,Publisher Rajawali Press, Jakarta

[34] Widodo, Putu T. (2016). Crime Scene DNA Sampling and Medical Aspects, socialization for Dokpol and Criminal Police Board Sutra Hall Dhacara Kendari of Southeast Sulawesi Police, dated April 11

[35] Yolanda, Ekky Elvira. (2017). Verification by inspection efforts DNA test and post mortem Bones Murder Victim Framework Affiliated with Other Criminal Acts (Studies Decision Number: 21 / Pid.B / 2016 / PNWNG),Thesis, Faculty of Law, University of March Surakarta.

[36] Yuniastanti, Inayah. (2006). DNA Test Result (Deoxyribonucleic Acid) As Evidence In jarimah Zina Alternative,Thesis, Faculty of Shariah Siyasah Jinayah Walisongo IAIN Semarang 2005/2006. 